\title{
The Logos between psychology, ontology, and Divinity: Fundamental aspects of the concept of Logos in the early thought of Slavoj Žižek
}

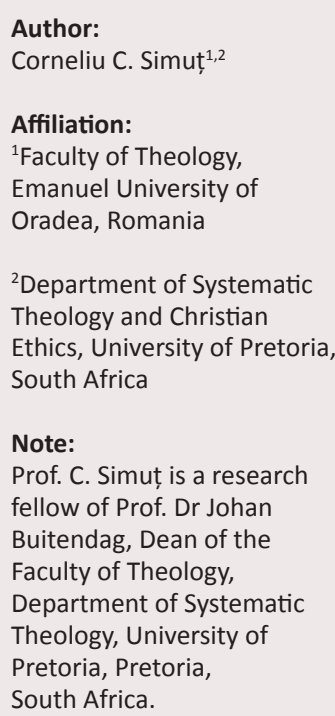

Slavoj Žižek's philosophy spans over more than three decades, which is confirmed by the numerous books he published since the late 1980s. Since his thinking about the idea of logos is no exception, this article focuses on what can be termed Žižek's early philosophy, and especially that depicted in his The sublime object of ideology (1989) and The metastases of enjoyment (1994). Whilst the former underlines the psychological aspects of the logos, the latter focuses more on theories about being, as well as on theological considerations. This is why, three uses of the logos were identified in Žižek's thought: psychological, ontological and theological, all three with a clear focus on the human being as conceived in modern thought, which for Žižek seems to be utterly opposed to traditional thinking about man and his relationship with God. It is clear from Žižek that whilst the notion of God does appear in this thought, it only refers to the human being which encapsulates the essence of Žižek's philosophy to the point that the logos itself is a fundamental feature of the human being's material existence in the natural world. Regardless of whether the logos points to psychology, ontology or divinity (theology), it always emerges as an idea which centres on the human being, with a special interest in how it exists as well as how it works in the world.

\section{Žižek and theology: An excuse to play with ontology}

Anyone who has ever heard of Žižek and most certainly those who read his works would confirm without hesitation that he is a philosopher - a philosopher 'to the bone', a man whose very essence is soaked in philosophy to the point that his discourses, books, articles and other productions are all imbued with philosophical themes, irrespective of whether he targets films, economic issues, jokes or books. Žižek himself enters numerous dialogues with Marx and Hegel, two names which without question would place Žižek's enterprise in the camp of philosophy, although he talks to both Marx and Hegel from the standpoint of Freud and Lacan, with the observation that he seems to like Lacan a bit more than he does Freud. Philosophy and psychoanalysis therefore are the categories which inform Žižek's thought: philosophy because that is what he does in writing, teaching, and interacting with society - his 'job' as some may say - and psychoanalysis for its capacity to 'fine-tune' his ontology, or his theory of being, which is generally seen as transcendental and materialistic when applied to his theory of subjectivity, as explained by Adrian Johnston (2008:69ff.), professor of philosophy at the University of New Mexico in Albuquerque, New Mexico.

To put a long story in a nutshell, Marx provides Žižek with communism and socialism as political theories which can be, in his view, viable alternatives to today's neo-liberalism, whilst Hegel offers him the chance to discuss the distinction between subject and object where the subject (namely the human being) needs to discover that the object (traditionally, the pre-modern image of God) is nothing or nobody else than the subject himself; in other words, God is man and man is God. Žižek's understanding of ontology in these terms was beautifully captured by Robert Paul Resch, who wrote a critical article on Žižek entitled 'What if God was one of us - Žižek's Ontology' (2005), where - in addition to unleashing his academic artillery on Žižek's notion of the subject and hence his perspective on ontology that is seen by Resch as 'obscurantist and incoherent' - one can easily see that Resch's question is actually rhetorical, so the answer is evident: In Žižek, God is of course one of us, a conclusion most likely endorsed by Resch (2005:89-90), a reputed professor of philosophy teaching at Texas A\&M University in College Station, Texas.

As for Freud and Lacan, they both instilled in Žižek an almost compulsive desire - lest one should say 'an obsession' - to 'dissect' the subject to the point that the subject understands his identification with the object. At the same time, however, the subject exists in society, the only real Other which Žižek seems to allow for his understanding of the subject. Žižek therefore tries to step beyond pre-modernity and its heterological understanding of ontology (i.e. ontology 
is dualistic in the sense that God and man are two totally distinct and real beings), to a modernistic, Enlightenmentbased understanding of ontology as a homologous reality in which God and man are the one and the same being living in the material reality of the physical nature, as confirmed by Matthew Sharpe (2004:4) who teaches philosophy at Deakin University in Melbourne.

Should one ask - quite rightfully so - what is Žižek's relevance for theology since he has been known as a philosopher, the best (and most likely the simplest) answer lies with the fact that he does talk about God. Despite his philosophical interests and influences ranging from Hegel and Marx (as indicated above) to Schelling, Heidegger and Derrida amongst others, Žižek just cannot rid himself of the idea of God. Raised by atheistic parents in the former communist country of Yugoslavia and today's Slovenia, Žižek has remained a faithful adherent to communism and socialism in politics, as well as atheism and some sort of 'death-ofGod' theology in religion, which can be traced back to Hegel and his 'death-of-God' considerations carefully analysed by Robert R. Williams (2013:139-140), professor emeritus of Germanic studies and religious studies at the University of Illinois in Chicago, and Martin Wendte (2007:266), currently teaching philosophy at the University of Tübingen. At the same time, the 'death-of-God' orientation places Žižek in the already notable tradition - discussed in one of my latest books (Simuț 2013:68-103, 112-120) - of Thomas J.J. Altizer, Harvey Cox, Gabriel Vahanian, William Hamilton and Paul van Buren who all pushed Žižek in the direction of the so-called 'Christian Atheism', analysed in detail by Brian Mountford (2011:1-5), the vicar of the University Church in Oxford.

In this respect, Žižek places himself between atheism and religious belief as 'radical atheism' which acknowledges that the 'big Other' (the pre-modern totally transcendent and utterly supernatural God of traditional theology) does NOT exist, as Žižek himself notices (2012:116). Whilst he does talk about God, Žižek's God can best be described in terms of atheism, an idea Žižek borrowed from Hegel, not from Marx as one may expect. Žižek is not a theologian, and neither is Hegel for that matter, but if Hegel can be presented as a theologian - see Vito Mancuso's first book Hegel teologo (Hegel Theologian), in which Hegel's concepts of truth, freedom and reconciliation are amply analysed (1996:5-33) by Italy's 'super-star' theologian and philosopher now teaching at the University of Padova - then I suspect it is not utterly or illogically inconsistent to speak of 'Žižek teologo' and present him as a theologian, at least for the purposes of this article. Since he does talk about God, although the God he has in mind does not exist within the traditional lines of premodernity, Žižek can be considered a 'godless theologian', as Adam Kotsko - teaching theology and philosophy at Shimer College in Chicago, Illinois - portrays him in his excellent book Žižek and theology (2008:137).

Žižek's numerous publications make him impossible to be ignored, so regardless of whether he is appreciated or not, both praises and critiques make his reception a genuine academic phenomenon. As a philosopher, he has acted as a critical theorist, but his 'unusual' and provocative approaches to social phenomena brought him the rather colourful label of 'the Elvis of critical theory', as suggested in The Chronicle of Higher Education. He was also compared with Yoko Ono and John Lennon for his endless lectures and talks given to students all over the world, as one learns from Scott Wilson (2013:29-30) who teaches cultural studies at the Institute of Technology in Auckland. At the same time, love and hate seem to be proper terms to describe one's interaction with Žižek's works; thus, his academic productions did not go unnoticed in the academy, whose reactions range from the Boston University scholar Kelsey Wood's appreciative Žižek: A reader's guide (2012:1-5) to Deakin University's Matthew Sharpe and Geoff Boucher with their academically engaging Žižek and politics: A critical introduction (2010:1-2). Sharpe and Boucher correctly see Žižek's active involvement in various social and cultural issues ranging from movies to the Iraq war, and from terrorism to the global financial crisis, coupled with a series of stern critiques for his 'serial offenses, including irresponsible provocations and political vacuity, moral blindness and totalitarian leanings, contradictory argumentation and slipshod referencing' (2010:1-2). The list of those who read and reacted to (or against) Žižek's works is a bit longer and it should include Noam Chomsky's (politely) derogatory - some may wish to consider them mildly disparaging - interviews currently available on YouTube; Chomsky, of course, needs no introduction for his exquisite work in linguistics at the Massachusetts Institute of Technology in Cambridge, Massachusetts.

My own position about Žižek is intentionally ambivalent in the sense that whilst I value his vivacious communication skills (reflected in books, articles, interviews etc.) and his tremendous publishing record - regardless of how it has been perceived by various academics - I utterly disagree with the content of his theology (or 'theology ' for that matter) as well as his political overtly aggressive support of communism, although he nuances his position in pointing out that he rejects its Leninist version as 'total madness' and 'a fiasco'. To me - and I acknowledge my bias in this respect - it does not really matter whether Žižek's communism is Leninist or not; having lived in a communist country during my early teenage years convinced me that communism was a political, social and economic failure coupled with a humanitarian disaster. I have always perceived communism as totalitarian and repressive, restrictive and enslaving, as well as violent and deceptive irrespective of how labels were changed on its forehead, whether it was branded 'communism' (for what it was in reality) or bore a different name - such as scientific socialism - under the same guise. Just in passing, one should know that Nicolae Ceauşescu, Romania's former president and leader of the Romanian Communist Party until his execution in 1989, was very fond of the phrase 'scientific socialism' which he seasoned with 'extremely anachronistic sermons on revolution, party, nation, and state,' as clarified by Ioan-Marius Bucur, professor of international relations at Babeș-Bolyai University of Cluj, and Crina Capota, a doctoral researcher at the same university (Bucur \& Capota 2007:398). 
Leaving aside my own perception of Žižek's position and regardless of whether his works are seen as 'refreshing' by Ilan Kapoor (2013:11), professor of critical development studies at York University in Toronto - or as giving 'irrationality a bad name' - Chomsky again! (2013) Žižek continues to write vigorously whilst his books are translated into English, French, German, Spanish, Italian and Norwegian. Thus, he unceasingly produces numerous writings on a wide range of philosophical and cultural topics which, here and there, present interest even to theologians: for instance, his God in pain. Inversions of apocalypse (with Boris Gunjević) and Less than nothing: Hegel and the shadow of dialectical materialism, both published in 2012 and presenting Žižek's logos as man's attempt to make sense of a dead God who exists only in man's belief in him (it).

This is why I said that Žižek's theology (or, more precisely, his thoughts on God, whatever he means by the word) is a mere excuse to 'play' with ontology; what Žižek does is to use the words 'God' and 'logos' in order to define the human being and whatever he understands by the notion of being. Of course, when he mentions the notion of God he does not refer to the pre-modern idea of God as an ontologically real, transcendentally distinct and personally accessible supernatural being other than the human being. On the contrary, when he writes 'God', he understands 'man', so Žižek's God is Hegel's modern 'absolute spirit' which overlaps with man's 'finite spirit', as indicated by Quentin Lauer (1982:134), a key name in Hegel studies. In other words, as far as Žižek is concerned, the logos is a religious-rational construct which stems from man's psychology as a subject struggling to accept his 'subjective objectivity', because the human being is nothing but a subject who tries to explain his objectivity by using - psychologically, ontologically, and even theologically - the idea of logos in the process.

\section{The Logos and psychology: The connection with man's intellect}

In Žižek, the logos is a concept which denotes the intellectual side of the human being, so there is first a psychological use of the logos. This is why he places it beside reason and language, both realities which define the existence of humanity in terms of thought and expression. This definition of the logos in Žižek as notion which points to man's intellect is heavily influenced by Freud and Hegel. First, Žižek borrows Freud's idea of the 'death drive' - competently tackled by Pamela Thurschwell (2009:86-87) - which does not point so much to the fact that man ceases its existence biologically but rather to the psychological functionality of man's brain which seems to be characterised by 'a blind automatism of repetition', also investigated by John R. Morss (1996:104). Žižek acknowledges Freud's conviction that man is a being in constant pursuit of pleasure as well as in a permanent attempt to preserve his life; these two facts are characteristics of man's life in the world or, to be more specific, in the materiality of the world. Self-pleasure, investigated in Freud by Dianne F. Sadoff (1998:55), and life preservation, researched by Ives
Hendrick (1958:125), are thus intellectual realities which go hand in hand with man's most fundamental death drive. Since death drive is a constant feature of the human being, so are self-pleasure and life preservation, which indicates that their basic features are repetition and automatism (Olkowski 1999:164). Nevertheless, regardless of how automatic and repetitive man is in his attempt to guard his life and endow it with pleasure, there is also an intellectual side attached to it, in the sense that both are considered in ways which are not instinctual, but rather carefully pondered and deeply analysed. It is here that the concept of logos finds its way in Žižek's Freudian perspective on humanity: Whilst instinctual when it comes to preserving his life and seeking pleasure for himself, man is also quite intellectual in heavily thinking about what happens to him, as Žižek (1989) points out:

Let us take the Freudian notion of the 'death drive'. Of course, we have to abstract Freud's biologism: 'death drive' is not a biological fact but a notion indicating that the human psychic apparatus is subordinated to a blind automatism of repetition beyond pleasure-seeking, self-preservation, accordance between man and his milieu. (p. xxvii)

Man uses his reason; he resorts to the reality of the logos or the capacity to set his reason in motion in a practical way which is illustrated by man's use of language. The logos, therefore, seems to be the link between the theoretical aspect of man's intellect, which is reason, and the practical aspect of man's intellect, which is language, a connection also noticed by Daniel Beaumont (2009:211, n. 14). To be sure, the logos represents man's ability to transform the theories of the intellect into the practicalities of language.

Secondly, Žižek refers to Hegel's notion of man as an animal who is 'sick unto death' (Kojève 2004:50), an indication of man's implacable fate as characterised by an impetus which forces him to consume himself from within (Hallward 2003:150). Man is not just an animal; man is an animal which thinks, uses his reason, and considers alternatives, so the capacity to think, coupled with the capacity to express his thoughts, is the very force that pushes man to the brink of his own death. According to Žižek, man is literally compelled to think and then express what he thinks; there is no way around it, man cannot avoid either thinking or practically displaying his thoughts. This is why, in Žižek, man is tormented by his own intellect and the power which lies beneath both man's capacity to think as well as his ability to put his thinking into practice seems to be the idea of logos. The logos, therefore, acquires a double connotation: Firstly, a native negativity which is given by the reality of man's death, and then a created positivity, which is the result of man's coping with the reality of death. As Adrian Johnston (2008:188) points out, man copes with death in a symbolic way because his entire life is under the influence of fictitious symbolism. In both cases, according to Žižek, the logos works actively in man's intellect as well as in his being, because as far as the native negativity is concerned, the logos helps man in accepting the reality of death in such a way that he is made capable of building his life whilst integrating it within his understanding of life. In Žižek, the logos helps man not only 
in defining the very essence of the human condition, but also in cropping a way of life which accepts the reality of death:

Man is - Hegel dixit - 'an animal sick unto death', an animal extorted by an insatiable parasite (reason, logos, language). In this perspective, the 'death drive', this dimension of radical negativity, cannot be reduced to an expression of alienated social conditions, it defines la condition humaine as such: there is no solution, no escape from it; the thing to do is not to 'overcome', to 'abolish' it, but to come to terms with it, to learn to recognize it in its terrifying dimension and then, on the basis of this fundamental recognition, to try to articulate a modus vivendi with it. (Žižek 1989:xxvii-xxviii)

This is also the image which defines the positivity of the logos, since the way of life which man devises for himself as expression of his human condition turns into culture, so in this respect, the logos is the source as well as the essence of human culture, a point made by Lori Branch (2006:33-34).

Žižek's conviction that the logos is the source of culture prompts him to postulate two consequences of this direct relationship between the logos and culture: Firstly, there is a separation between the human being and nature, competently investigated by Charles Shepherdson (1996:163); and secondly, the powerful impact which the human being has on nature, elaborated by Joseph Dodds (2012:125-126). In other words, as far as the human being is concerned, there is a laceration from nature and a laceration of nature. Regarding the first issue, the laceration from nature, Žižek explains that since the logos is man's capacity to connect the theoretical aspects with the practical aspects of the intellect, namely reason with language, one can easily see that logos is the source of man's cultural expressions which reflect themselves in man's natural life (Myers 2003:36-37). The things which are theoretically conceived by the human being through the mediation of reason and then are practically built in the materiality of nature produced the effect of a breach between man, in his capacity of creator, and nature, as context for both man as creator and man as part of creation. Man as creator points to idealism, whilst man as part of creation speaks about materialism, so by placing the two aspects together Žižek seems to attempt to move beyond the distinction between idealism and materialism, as noted by Tom Eyers (2011:157). Nature can be considered creation since the things man conceives theoretically through reason are eventually produced based on materials taken from nature. Thus, whilst nature precedes creation in the sense that it hosts the human being as creator, it also lies at the very basis of creation given man's capacity to use its raw materials for the process of creation. Hence Žižek's belief in the detachment of the human being from nature: Man himself is part of nature in a physical way; intellectually though, by using reason and the expression of language, man began to create a wide range of things which placed him above the rawness of nature. Nature makes no sense to man unless man uses his reason, or the logos, to create out of it or based on it. This is why Žižek compares the creative task of the human being with that of a trained historian: History makes no sense to the historian unless he uses his intuition and reason, his logos with all its psychological capacities, to interiorise whatever he sees lying outside, in the open, within his very self and his inner selfconsciousness:

Nothing whatsoever can succeed in coming immediately to consciousness, not even what is given from the outside. Everything must first become inward. If the past does not awake from within the historian himself, then he will never present it as true, as intuitive, as alive. What would all of history be, if an inner sense did not come to its aid? It would be what it is for so many who indeed know all about what has happened without understanding the slightest thing about genuine history. Not only human events but even the history of nature has its monuments, and one can well say that they do not leave a single stage along the lengthy path of creation without leaving behind a mark. These monuments of nature lie for the most part in the open; they are thoroughly researched, in part genuinely deciphered, and yet they tell us nothing but rather remain dead until that succession of actions and productions has become inward. Thus, everything remains incomprehensible to man until it has become inward for him; that is until it has been led back to precisely that innermost [aspect] of his essence which is for him the living witness of all truth. (Žižek 1997:116)

Man thus became creator and, through the practical application of the logos, he separated himself from nature in an intellectual way whilst still remaining part of it. Consequently, man's detachment from nature appears to have been an intellectual triumph for the entire humanity, because creation presupposes inwardness and selfconsciousness which in turn produce truth. This triumph, however, is not to be understood in a triumphalist way; it is not positive, but rather negative because man's capacity to use his reason or logos makes man realise that he is neither divine, nor part of a divine plan, an explanation offered by Thomas Brockelman (2008:31).

Nevertheless, what proved to be a victory from the standpoint of man's intellect eventually resulted in a catastrophe from the perspective of ecology. When man cut 'his umbilical cord with nature' - a phrase analysed by Aranye Fradenburg (2002:152) - as Žižek puts it, by using the logos so that theoretical reason became practical intellect, man not only separated himself from nature; he also profoundly and irremediably wounded nature. This is why man's intellectually fortunate laceration from nature became an ecologically misfortunate laceration of nature; man's creation turned into realities which began to harm the natural source of creation itself, the very nature in general. As a result, by using the logos, man shattered the original balance of nature to which there is no return, as Žižek apocalyptically predicts and in doing so gets noticed by Dennis K. Keenan (2005:58). Žižek is utterly sceptical when it comes to the assessment of what the logos produced in nature; the negativity of his convictions reflect the negativity of the logos and ultimately the negativity of human culture. The seemingly positive laceration of the human being from nature resulted in fundamentally negative consequences because man was misled to believe that he was superior to nature, which in Žižek is definitely not the case. He also explains why: When man is convinced that, based on his capacity to unite reason with language, 
theory with practice through the logos, he deceives himself in believing that he somehow managed to rise above nature. This conviction deeply penetrates man's reason to the point that he believes in the so-called 'harmonious being', which for Žižek is a false image of humanity as suggested by Jan Jagodzinzki (1997:210). There is no 'New Man', Žižek apocalyptically claims, and there will never be one, precisely because the human being is made to be antagonistic, an idea promptly grasped by Geoff Boucher (2005:44). The illusion of the final defeat of man's innermost antagonism is the very source of 'mass murders and holocausts', all committed in the name of the false New Man, namely man's greatest lie which he administered to himself in believing that his inborn antagonistic tension can be eventually suppressed. Since this cannot be done but man still falsely believes in his nonexistent inner harmony, society is faced with the constant threat of totalitarianism, which builds on the illusion of man's return to nature instead of openly admitting man's most essential departure from nature. Here is Žižek's (1989) 'realised apocalypse' in his own words:

All 'culture' is in a way a reaction-formation, an attempt to limit, canalize - to cultivate this imbalance, this traumatic kernel, this radical antagonism through which man cuts his umbilical cord with nature, with animal homeostasis. It is only that the aim is no longer to abolish this drive antagonism, but the aspiration to abolish it is precisely the source of totalitarian temptation: the greatest mass murders and holocausts have always been perpetrated in the name of man as harmonious being, of a New Man without antagonistic tension. We have the same logic with ecology: man as such is 'the wound of nature', there is no return to the natural balance; to accord with his milieu, the only thing man can do is accept fully this cleft, this fissure, this structural rooting-out, and to try as far as possible to patch things up afterwards; all other solutions - the illusion of a possible return to nature, the idea of a total socialization of nature - are a direct path to totalitarianism. (p. xxviii)

The $\log o s$, therefore, although intellectually positive in helping man explore his creative capacities proves to be a negative reality when it comes to judge its effects on nature. This means that we need to rethink ethics in the sense that there is no universalistic perspective on morality which should be imposed on how various people understand the idea of good and evil. According to Žižek, it is not a common ethics which unites humanity, but rather 'the same antagonism', a conclusion reached by Johann-Albrecht Meylahn (2011:5). As the source of the current ecological disaster, interestingly discussed by Erik Swyngedouw (2010:188), the logos not only separates man from nature, but also completely detaches nature from man, who is totally unable to abolish his innermost antagonism. This negativistic state of affairs is what characterises the human being and there is no escape from it unless man is ready to acknowledge and accept it as the essence of his being. Žižek illustrates man's essential antagonism by pointing to the relationship between sexes. Feminism, therefore, has no real basis because there is no equality between sexes. There is 'no final solution', as he puts it, the existence of the sexes proves that the human being is fundamentally antagonistic and there is no way in which the use of reason through the practical application of the logos in the reality of nature can somehow deconstruct man's constitutional lack of balance. The only thing man can do is to embrace this imbalance and, when (if) this happens, then the intellectual positivity of the logos may not constantly lead to the disastrous consequences of the negativity of man's laceration from and of nature, a feature which seems to be the very essence of man's being (Žižek 1989:xxviii).

\section{The Logos and ontology: The essence of man's being}

As far as Žižek is concerned, the logos also refers to the reality of being - so the second use of the logos is ontological - which is discussed in connection with the notion of the Other, also studied in great detail by Rex Butler (2005:54-55). Whilst the Other conveys the idea of transcendence, namely a reality which goes beyond the subject, Žižek mentions the logos in the context of what he calls 'the decentrement of the Other'. In other words, the logos - which defines the essence of being since it works with the intellect - assists the subject in realising that the idea of the Other is not an ontological reality, which in turn is potentially a psychotic discovery, as pointed out by Simon Cooper (2002:148). This is to say that the Other cannot be conceived as fundamental transcendence referring to the human subject; man, as a being, does not exist in a reality which is transcended by another ontological reality wherein the Other exists in a real ontological way. To give the classical example of traditional theology: Man exists in the reality of the natural and material world as an ontological being, whilst God exists in the reality of a supernatural and non-material world also as an ontological being; this is why, such a God is the Other for the human being. Žižek refutes this understanding of reality by stressing that the logos, or man's capacity to use his reason both theoretically and practically, helps the human being understand that there needs to be a 'decentrement of the Other', a displacement of the Other from its traditional transcendent (ontological) status. Thus, for Žižek, God does not exist as an ontological being whose existence is given by a fundamental alterity compared to the human being; this is why Sharpe and Boucher (2010:205) suggest that God, or the Other, must no longer be defined in terms of an ontological transcendence of being. The logos assists man, the subject, in grasping the fact that the Other must become the subject itself, a realisation which is defined as 'absolute negativity' - a phrase that caught Alex Callinicos's attention (2006:114) - because man grows to understand that there is nobody beyond his being or beyond his world, in which the only constant reality appears to be death. The acceptance of this absolute negativity is based on the conviction that the subject is the subject and nothing or nobody else; as Žižek puts it, 'I = I' - more details about this equation are offered by Geoff Boucher (2008:184) - so in my capacity as human being, I understand that what has been traditionally defined as the Other, or God, is not a supernaturally transcendent being who exists beyond the material world but the Other is my very own self, the material and mortal human being who lives in the materiality of nature: 
Here we confront the decenterment of the Other with regard to the subject, on account of which the subject-as soon as he returns from the 'night of the world', from the absolute negativity of I = I, into the 'daily world of logos' - is caught in a network whose effects a priori elude his grasp. (Žižek 1994:42-43)

The full realisation of this absolute negativity can only be caused by the logos, although the human individual as subject can never completely understand the complexity of such a realisation. In Žižek, the logos seems to help man rid himself of ideologies and fantasies, one of the most damaging of which being man's desire to centre 'the Other' in a reality other than his own self (King 2010:11). Thus, by using the logos, man is able to realise that the Other is himself, which also means that man can transcend himself through the logos, although this transcendence as well as man's existence are definitely confined to the material world of nature. Consequently, God becomes ontologically absent, but only from the perspective of traditionalist (transcendentalist) thinking about God. This is confirmed by the fact that, according to Žižek, the one who preaches the ontologically real God, namely the apostle, founds his testimony of a transcendent authority, when in reality the apostle is nothing but a genius who should display - in a representative way - the highest qualities of the human being, as proposed by Leo Stan (2011:307).

What man is incapable of fully understanding has to do with the intricacies of the material and non-material - that is, psychological - reality in which he exists as a being who constantly decentres the idea of the Other into his own being. It is crucial to understand here that, in Žižek, the decentrement of the Other, seen as an objective reality, represents the accomplishment of man's subjective self-consciousness, an idea advanced by Uradyn E. Bulag (2010:8). In fact, Žižek (1998) acknowledges that there is a:

paradoxical complicity of the two aspects of self-consciousness: the dimension of subjectivity is irreducible, the subject's selfacquaintance is always already presupposed in all our acts, the gap between the subject's immediate self-experience and the mechanisms of its objective genesis is constitutive, which is why one cannot reduce the subject to an effect of some underlying objective process. (pp. 247-248)

One can now see why there is a need in Žižek to destroy any 'objective process' which may interfere with man's selfconsciousness; the traditional pre-modern idea of God is such an 'objective process' perceived as 'the central Other', which - according to Žižek - must be destroyed or decentred, an action that can be carried out by means of the logos. Thus, by using the logos to redefine the transcendence of the Other from a supposed supernatural existence to a demonstrated natural ontology, man not only understands that the Other is his own self and that what has been traditionally defined as God is a reference to his own ontology, but also that this realisation defined by sheer negativity raises the level of his own consciousness. Consequently, man is no longer supposed to found his life on the consciousness of the Other, but rather on his own self-consciousness. Man, therefore, acquires a new sense of responsibility - or perhaps irresponsibility? - which is anchored in his own being and awareness of himself, a fact that did not escape Fabio Vighi (2010:103). The logos, as it were, helps man become aware of himself, of his capacity to think, reason and produce theories which can be then applied in daily practice; logos produces in man a sense of awareness which no longer clings to the traditional transcendence of the Other but on the self-transcendence of man's own being. In other words - Peter Dews suggests (1995:248-249) - man understands his limitations as well as the fact that his limitations are constitutive to his being. This is why, by using the logos, the traditional ontological transcendence of the Other becomes in Žižek a mere intellectual or rational transcendence of man's biological existence (Žižek 1994:42-43).

In Žižek's thought, therefore, the logos is concerned with the epistemology of being, because one not only finds out how being should be defined (with or without reference to the ontology of the Other), but also how being itself works. Since for Žižek transcendence is no longer a reality of the Other because it characterises only the human being, it is important to realise that the sole realm of man's existence is the materiality of nature. This conviction - aptly singled out by Thomas Keenan (1997:184-185) - has ethical implications, such as the fact that man's capacity to transcend his materiality by means of spirituality (symbolisation) must be kept in a state of autonomy. In the material world, however, the corporeal existence of the human being involves a wide range of psychological manifestations, in which Žižek appears to be highly interested. In order for him to explain how the being works, he resorts again to Freud, and then to Kant. From Freud he borrows the idea of the 'unconscious' investigated in Freud by Güven Güzeldere (1997:20) - which, as far as Žižek is concerned, goes hand in hand with the notion of 'infinite judgment' taken from Kant (Guyer 2006:76). Both concepts, Žižek explains, point not only to man's complex psychological and biological constitution, but also to the way the two are intertwined within the human being's most basic functionality. In Žižek, the Freudian 'unconscious' - seen as a dynamic process by Henk de Berg (2003:5-6) - and the Kantian infinite judgment' - analysed by Georges Dicker (2004:55) - appear to indicate that the human being is capable of stepping beyond its own physical-corporeal confinement through a dynamic process which involves reason, namely the logos. In Žižek's (1994) words:

This is why self-consciousness is strictly correlative to the Unconscious in the Freudian sense of the term, which is akin to the Kantian infinite judgment: when I assert about a thought that 'it is unconscious', this is quite different from asserting that such a thought 'is not conscious'. In the latter case - when I negate the predicate 'conscious' - the (logical) subject is simply located in the domain of the non-psychic (of biology, and so on - in short, in the vast domain of all that goes on in our body beyond the reach of our consciousness). (p. 43)

The human being therefore seems to have the capacity to move outside the limits of his biological constitution, does not seem to be restricted to the ability of the individual human person, at least not primarily. On the contrary, 
it seems that humanity in general is able to exist in such a way that it functions in total dependence not only of its psychological and biological components, but also of its supra-psychosomatic awareness. Curiously though, this awareness is essentially unconscious, not in the sense that the individual human being is unable to make sense of its existence, but rather in the sense that it cannot be deciphered consciously; for instance, man is able to think consciously about things he then practices unconsciously, such as religion (Easthope 1999:146). It appears thus that man's suprapsychosomatic awareness is Žižek's way to speak about man's transcendence. Man's existence in the world or, to be more specific, in this world, is far too complex to be reduced to the things than can be known scientifically because these would, quite naturally, pertain to man's ontological constitution. It should be said here that the reality of this world is of paramount importance for Žižek because the very essence of Christianity has to do with man's desire to became 'truly alive' as if humans were the 'living dead' who want to turn or return to real life (Turnbull 2005:144-145). What Žižek seems to advocate here is the fact that man exists in a web of extremely complex realities which escape the actual ontology of his psychosomatic body. In other words, there are things in this world which cannot be explained in a conscious way, but can be accepted - in the sense that man is aware of them - in an unconscious way. One example of a reality which man is aware of in an unconscious way seems to be the Eucharist. According to Žižek, what happens at the Eucharist - as Tina Pippin writes (2010:12) - is that man's body is literally invaded by the 'undead substance' of Jesus' zombie-like body.

Consequently, in Žižek, there are three levels of reality: biology, psychology, and - in the absence of a better term since Žižek himself does not capture it in a word - supramateriality. In Žižek, the unconscious appears to refer to what can be called 'unconscious forces', realities which repeat themselves as time elapses and which Žižek designates by using the term 'Real'. The Real, as the sum of these unconscious forces, is opposed to reality, which refers to man's conscious desires. There is a gap between the Real and reality, namely between the unconscious drives of which man is fully aware (in a spiritual way, rather than in a scientific way) and man's conscious desires. The result of this gap on the human being is horror, because man is aware of these drives which he cannot explain scientifically, but only accept spiritually, so in order for him to make sense of them he uses the logos, or his reason, as proposed by Clayton Crockett (2007:121-122). Although the realm of supra-materiality is essentially unconscious, humanity is totally dependent on it for its proper functionality, and we know this thanks to the logos being seen as man's capacity to understand even the things which cannot be comprehended or demonstrated scientifically. Supra-materiality tends to evade science precisely because it has nothing to do with the ontology of man's biological constitution. Man's supramateriality, which is in fact his fundamental transcendence, is therefore - and Žižek resorts to Lacan for a proper definition - essentially 'pre-ontological', a concept investigated by
Nathan Widder (2008:57), Dany Nobus (2000:82) and Ashraf H. Rushdy (1992:43). This is Žižek's (1994) explanation:

When I affirm a non-predicate and assert that the thought is unconscious, I thereby open up a third, uncanny domain that subverts the very distinction between psychic-conscious and somatic, a domain that has no place in the ontologicalphenomenological distinction between psychic and somatic, and whose status is for that reason, as Lacan puts it [...], 'preontological'. (p. 43)

In other words, the complex net of realities which goes beyond man's individual biology and psychology into the realm of unconscious awareness, appears to exist before and even without the physical existence of a certain human person. This is why, for Žižek, the third level of man's existence as being (in addition to biology and psychology) rises above the level of ontological phenomenology; there is no such a thing as 'objective knowledge' simply because - as reaffirmed by Isleide Arruda Fontenelle (2010:269) - some realities cannot be known in a scientific way. The logos, however, manifests itself within all three aspects of man's being, because whilst it helps man understand what Žižek calls the 'distinction between psychic and somatic' - this seems to be borrowed from Freud, where the distinction between psychic and somatic is compared with the distinction between the representation of a particular human drive and the drive itself, as we are reminded by Elisabeth Bronfen (1998:85) - it also assists man in realising that there is a metaphysical (here in the sense of supra-material) level of existence which is essentially unconscious precisely because the individual human being is not able to make sense of it, or of his experience in general, in a fully conscious way. It should be stressed here that, in Lacan, language influences the unconscious in the sense that whilst language is always connected with 'the Other', it can never comprehend the totality of man's experience. Thus, there is something in man's existence which cannot be represented in any way whatsoever, and that is known through the unconscious, as shown by Tomasz Szkudlarek (2011:116). The logos, therefore, is able to show man that supra-materiality is a reality, so man can be fully aware of it, but not through the avenue provided by consciousness. To be sure, the logos does not predicate a supra-materiality beyond materiality (meaning that supra-materiality can exist without materiality), but rather a supra-materiality above materiality (in the sense that supra-materiality cannot exist without materiality). In other words, although man becomes aware of supra-materiality in an unconscious way (so it cannot make sense of it scientifically), Žižek concludes that supra-materiality - which essentially precedes the ontology of human individuals - is totally dependent on the ontology of humanity as a whole (Žižek 1994:43).

\section{The Logos and Divinity: The symbol of man's divinity}

Despite man's capacity to investigate reality - the reality of his own self in close relationship to the reality of material nature - in a way that focuses on man himself, Žižek cannot avoid using the concept of God even if he deliberately chooses 
to focus on the key importance of man's role for his in-depth research of human existence. Žižek senses the necessity to use the idea of God when he speaks of man, so his use of the logos in this respect - which is theological in nature places the logos and God together. The intention here is to connect the logos with the idea of the absolute, the essence of the totality of concepts and decisions, as suggested by Ian Biddle (2011). In this respect Žižek points to Schelling and his theory which connects the logos and God in an argument focusing on the reality of creation, in an attempt to reconcile the things which cannot be seen (logos and God) with the things which can be seen (creation), a connection which was thoroughly investigated by Patrick Burke (1999:183-208). Quite obviously, Schelling's idea of creation is not that of traditional theology which focuses on the language of ontology (in the sense that God and man are ontologically real as actual beings to the point that both possess an existence endowed with ontological status, personhood and personality), and this is exactly why Žižek employs it in speaking about the human being. If the connection between God and the logos is not ontological, then it can be conceptual; God and the logos are ideas which, in the end, point to man's material constitution and functionality. Thus, Žižek borrows from Schelling the conviction that the logos emerges from the 'abyss of the "real in God", of the vortex of drives' - which caught Rüdiger Safranski's interest (1989:313) - a formula resembling man's psychological faculties. The abyss seems to indicate man's unconsciousness, which is coupled with a highly complex interpenetration of a wide range of biological urges that are physically located in the reality of man's being. The 'real in God', therefore, is in fact the 'real in man' because Žižek refers to Schelling's conviction that this definition of God - industriously studied by Douglas Hedley (2004:80) - presents God before the creation of the world, as a being endowed with personality. In Žižek's (1994) own rendering:

Schelling [...] deploys the programme of deriving the emergence of the Word, logos, out of the abyss of the 'real in God', of the vortex of drives [Triebe] that is prior to the creation of the world. Schelling distinguishes between God's existence and the obscure, impenetrable Ground of Existence, the horrendous pre-symbolic Thing as 'that in God which is not yet God'. (p. 129)

It has to be stressed here that, in Schelling the creation of the world should not be understood in ontological terms; thus, it is not the actual building of the material world by a non-material God. On the contrary, it is the building of the world in an artistic way; man - defined in divine terms as God - creates the world through the mediation of the logos, his capacity to transform nature in an intellectual as well as practical way. At the same time, creation may refer to the self-revelation of God; in this case, the self-revelation of man, an idea proposed by Devin Z. Shaw (2010:133). Žižek appropriates Schelling's perspective and incorporates it into his own understanding of man and in so doing he shows that man's capacity to transform the world intellectually and practically has always been latently present within his own being even before he began to transform or to create the world. This reality can be applied both to humanity in general and the human being in particular; the logos or the capacity to transform the world due to man's intellect and reason, is present in man from the moment of his appearance in the world. Long before the human individual was able to use his intellect in a transformative or creative way, the logos was surely present in man's psychosomatic constitution of his biological body.

Consequently, Žižek appears to support a distinction between the creative human being (man when he reaches the capacity to create) and the non-creative human being (man before he reaches the capacity to create), an issue debated by Laikwan Pang (2012:37) who delves into a comparison of Žižek and Schelling. This separation is evident in man's psychological manifestation: Man first exists in a state of non-creativity and then he develops his capacity to transform the world. In symbolic terms, and here Žižek dwells on Schelling again, there is a difference between God's existence (which is in fact man's existence) and the 'ground of existence' - which proved to be so interesting to John Laughland (2007:73) - most likely the complex network of psychological realities which defines the human being, both as an individual and as a race, and which displays his non-material abilities. For Schelling, there is something in God which is not yet God, in the sense that a certain reality pertaining to God's being still needs to develop itself. In Žižek, this means that there is something in man which still needs to emerge towards maturity, and such an understanding of the human being can only be supported if understood psychologically and symbolically. Žižek is indeed interested in the connection between the ground of existence and symbols, which is tackled in his Organs without bodies (2012b:67-68). In Schelling, God is defined simultaneously by contraction and outpouring, by hate and love, by a preoccupation with himself and a preoccupation with others. Such a definition though is meant for man because, in Žižek, this dual constitution of God is a clear reference to the human being, which is in constant need of emancipation, as seen in Steffen Böhm and Aanka Batta (2010:351). To make things clear, but also to explain Schelling's position, Žižek resorts to Freud's distinction between the libido and the death drive, two psychological realities which define the human being throughout its existence. Man's psychological constitution, which is fundamentally antagonistic in Žižek as he follows in the footsteps of Schelling and Freud, manifests itself outwardly and the means whereby man externalises his inner psychology is the logos. In fact, the logos - Žižek writes is capable of transforming man's antagonistic psychology in a 'symbolic difference', on which Tina Pippin (1999:46) offers valuable insights. To quote Žižek (1994):

This Ground consists of the antagonistic tension between 'contraction [Zusammenziehung, contractio]' - withdrawal-intoself, egotistic rage, all-destructive madness - and 'extension' God's giving away, pouring out, of his Love. (How can we fail to recognise in this antagonism Freud's duality of the ego drives and the love drives that precede his duality of libido and death drive?) This unbearable antagonism is timelessly past; a past that was never 'present', since the present already implies logos, the clearing of the spoken Word that transposes the antagonistic pulsation of the drives into the symbolic difference. (p. 129) 
In other words, man's psychology is able - through the active use of the $\log o s$ - to create symbols which can be then transposed, in a transforming way, in the practical reality of the material world. As highlighted by Christian De Cock and Steffen Böhm (2007:825), man sees reality not necessarily as it is but through the mediation of his own fantasies, so the raw materiality of nature needs to go through a process of symbolisation. This includes the notion of God which, in Schelling, becomes a symbol for the human being, a creative transposition which Žižek appears to accept without reservation (Žižek 1994:129).

The idea of God in Žižek is not very easy to comprehend especially when tied up with Schelling's perspective on divinity. Schelling's God, at least in his early writings, is fundamentally ambivalent; contraction and expansion are, therefore, two realities which define God's being, as noticed by Judith Norman and Alistair Welchman (2004:4). There is another aspect, however, which needs to be taken into account, and this is history. According to Schelling's view, as explained by Žižek, history seems to stand between God's contraction and his expansion, an issue detailed by Martin Wallen (2005:131). In other words, history is the liaison between God's hate and God's love, which - as suggested by Jason M. Wirth (2003:188) - seems to be an influence going back to Jakob Böhme. As far as God's being is concerned, history begins only after God's contraction ends, so contraction or hate (even madness) is a feature of God which belongs to prehistory. God's contraction though needed an equally powerful counterpart, so God acquired for himself an expansion, which was the very ground of his existence as a subject. Before that, God was defined by the sheer negativity of his contraction (madness) (Faflak 2005:210). After he acquired his being, God becomes a positive entity which dissipates love in the world which he created soon after his being came 'into being'. When God leaves aside his contraction to become a being, he not only creates the world, but also speaks the logos or the word, and then he creates his son, an idea also underlined by Wilhelm Schmidt-Biggemann (2004:462). This is how Žižek (1994) understands Schelling's early view of God:

God is thus first the abyss of 'absolute indifference', the volition that does not want anything, the reign of peace and beatitude [...] the pure expansion into the void that lacks any consistence, the 'giving away' held together by nothing. God's 'pre-history' proper begins with an act of primordial contraction by means of which God procures himself a firm Ground, constitutes himself as One, a subject, a positive entity. Upon 'contracting' being as an illness, God gets caught up in the mad, 'psychotic' alternation of contraction and expansion; he then creates the world, speaks out the Word, gives birth to his Son, in order to escape his madness. Before the emergence of the Word, God is a 'depressive maniac', and this provides the most perspicuous answer to the enigma of why God created the universe - as a kind of creative therapy that allowed him to pull himself out of madness ... (p. 130)

Schelling's thoughts about God, however, are almost impossible to comprehend if compared to traditional Christian theology, which considers God the completely ontological Other, the very idea Žižek wants to see demolished.
In Schelling though God cannot be considered the completely ontological Other despite the fact that prehistory is attached to it, an aspect which did not escape Žižek's reading. One should see here that prehistory is coupled with the non-existence of creation and the nonutterance of the logos, whilst in traditional Christian theology prehistory and the non-existence of creation go hand in hand with the existence of the logos. Thus, the logos is pre-existent - in the sense that it predates both history and creation - which in Schelling is not the case. One can conclude then that Schelling's God is a reference to the human being before its ability to creatively transform history into symbolic, intellectual and artistic concepts which were then transposed in the materiality of nature, an idea rejected by Garry Dorrien (2012:200). Such an understanding of Schelling's early theory of God is confirmed by Žižek who points to the fact that Schelling's later view of God is imbued with the idea of revelation which, in turn, dwells on God's pre-existence, as stressed by Joseph S. O'Leary (2006:190). God possess his existence before his contraction. Thus, God's pre-existence leads to God's contraction which then produces the creation of matter - a view which comes closer to traditional Christian thought because the logos is no longer the result of God's creation but rather a feature of God's pre-existent state. This means that, in God there is no longer a direct correlation between existence and the ground of existence but between existence and essence, both pointing to the being of God. In its capacity of the essence of (Schelling's) God, the logos, Žižek explains, must find a 'positive existence' (Žižek 1995:489) to realise - in the sense of enactment - the love of God in a practical way, namely in the material world of nature, which then points to the incarnation of the logos and its indwelling amongst, as well as in, human beings:

The late Schelling of the 'philosophy of revelation' recoiled from his previous radicality by conceding that God possesses his existence in advance: contraction now no longer concerns God himself; it designates solely the act by means of which God creates the matter that is later formed into the universe of creatures. This way, God himself is not longer involved in the process of 'genesis': genesis concerns only creation, whereas God supervises the historical process from a safe place outside history, and guarantees its happy outcome. In its withdrawal, in this shift from Weltalter to the 'philosophy of revelation', the problematic of Weltalter is translated into traditional Aristotelian ontological terms: the opposition of Existence and its Ground now becomes the opposition of Essence and Existence - that is, logos is conceived as the divine Essence that needs a positive existence if it is to achieve its effectuation, and so on. (Žižek 1994:130)

Either way, however, Schelling's God is merely a theorising of man's existence in nature, which attempts to explain man's non-material, psychological, and - generally speaking - spiritual manifestations in the otherwise fundamentally material world.

Žižek does not criticise Schelling's perception of the idea of God, which - although is not in itself a proof that he 
endorses it - can be indicative of a somewhat tacit acceptance (Pound 2008:28-30). In Žižek what appears to really matter is not the idea of God, but rather the notion of logos which regardless of Schelling's early or later view of God - cannot be detached from the definition of God (Mandair 2009:398). It is not important whether God was characterised by existence before or after creation; what is important in this context has to do with the fact that the logos explains God's existence with reference to creation, a reality to which man relates in terms of rupture or break since God - a reference to man - goes from contraction to expansion, from love to hate; in other words, there is a pattern of fracture in man's existence within this world, which was analysed by Saul Newman (2004:310). God may or may not have existence before creation but the logos indicates that God's existence cannot be defined without the idea of creation. Since creation is essentially comprehensive in conjunction with materiality, God is also explained from the perspective of the material world, which is the foundation as well as the context of man's existence, with the aid of the logos. It is the logos, Žižek seems to imply, which defines God from the perspective of man's material existence in the natural world irrespective of whether God's existence precedes or stems from creation. Since creation is fundamentally material, God's existence cannot be severed from it, and because the analogy of God's existence is the existence of the human being - a connection made possible through the symbolic use of the logos - it is logical to conclude that God is just another word for man.

This is why one must understand that the shift from existence and the ground of existence to essence and existence in Schelling is not necessarily so dramatic as it appears - an issue which is clear to Žižek. The only novelty presented by the latter is that it allows for the idea of pre-existence, which - if coupled with the redefined notion of transcendence keeps the reality of the human being within the confinement of the materiality of the world. Žižek seems to be aware of this since he does not choose to offer further comments on Schelling, whose philosophy of revelation does not distance the definition of God from that of the human being, but rather makes things a little more complicated since - if applied to man - pre-existence points to man's collective nonmaterial characteristics as race which precede the actuality of the ontology of each human being. For instance, as Žižek manages to demonstrate (1994:130), human culture can be said to be pre-existent with reference to the actual life of a certain human person, because it precedes its coming into being and - at the same time - it follows after man ceases to exist as a person.

\section{Conclusion}

There are three uses of the notion of logos in Žižek's early thought: psychological, ontological, and theological. The first focuses on man's intellect and is predominantly Freudian as well as Hegelian. Thus, the logos points to man's ambivalent psychological constitution which bounces between selfpleasure and self-preservation on the one hand, and the acute awareness of death on the other. Consequently, the psychological use of the logos in Žižek underlines the antagonistic nature of man's psychology which moves from the positivity of pleasure to the negativity of death. In using the logos to define man's psychology, Žižek does not intend to reconcile positivity with negativity; it is quite the other way around, namely that Žižek wants to establish as well as fully recognise the ambivalent, antagonistic, and conflictual nature of man's psychology, a conviction which he borrows from Freud. As far as Hegel is concerned, he supplies Žižek with the connection between reason and language, which is performed by the idea of logos. In this respect, the logos points to a specific human ability which turns the theoretical aspects of reason into the practical features of language. The antagonistic duality of man's psychology is evident here as well, especially when Žižek points to the fact that the logos is the connection between non-materiality or spirituality and materiality. The result of man's antagonistic psychology is also dual in the sense that, whilst on the one hand man detaches himself from nature as a result of his use of the logos, he also produces a powerful impact upon nature. According to Žižek, man's separation from nature is characterised by positivity because it has to do with man's capacity to create, or turn the theory of reason into the practice of things; man's impact on the other hand is sheer negativity, because the things man produces tend to be the things that eventually cause destruction throughout nature.

The second use of the logos in Žižek is ontological and it describes the essence of being; to be more precise, it is the human being, but the definition of man in this case is done through the mediation of the concept of the Other. Žižek refers to the decentrement of the Other, by which he means that the Other - which traditionally points to the exteriority of the human being, even to another being, such as God needs to be ascribed a new centre. The idea of the Other, traditionally associated with God, must shift its classical focus from God - who is fundamentally different from man - to the rather modern direction of man. The centre of the idea of being, therefore, must be rooted out of its classical understanding as predominantly pointing to God in order for it to be anchored in the reality of the human being. The decentrement of the Other, which is done by using the logos presented here as man's capacity to see himself as the Other - presupposes the shift from the spirituality of God's being to the materiality of man's being, a shift that can be realised only in conjunction with the notion of transcendence. What Žižek does here is to redefine transcendence, which is no longer God's but rather man's capacity to understand the non-material features that define his existence in the world. By using the logos, man understands that the Other is himself, and the things which he cannot comprehend since they belong to the realm of unconsciousness, are still part of this material existence in the world. The idea of unconsciousness comes from Freud, as Žižek points out, but this is coupled with Kant's 'infinite judgment' since both point to man's transcendence. In the end, man's transcendence refers to the extremely complex web of non-material realities that transcend the existence or the ontology of individual human persons. It is for this reason that man's transcendence is 
pre-ontological, a term Žižek borrows from Lacan, because the unconscious realities which define man's awareness of himself and his existence in the natural world exist before, as well as after, a certain individual human being ceases to exist in a material, physical, biological, and psychological way.

This brings Žižek to the third use of the logos, which is fundamentally theological. If in Freud and Lacan the nonmaterial realities of the human being are transcendent in an unconscious way, so man is aware of their existence although he cannot fully explain them, in Schelling they become part of the realm of God. The image of God in this case is not that of the God of traditional theology, but rather the God described as the abyss, the sum of all the things man cannot comprehend in a rational way. From this perspective, the idea of God is, again, connected with the human being, because it is man who becomes aware of the things he does not understand. The idea of creation is crucial here because man is seen as a being who is not only capable of creativity, but it also creates things which become material. Man's creativity, a feature of God, turns into actual products (which can be spiritual or material) by using the logos, but what is more important here, in Schelling, is the fact that man's creativity has an evident symbolic aspect. Man thinks of God and about God, so in this sense, man creates God in a symbolic way by using the logos, which is the capacity to connect theory and practice, reason with language, although in Schelling, the capacity to create is said to be God's sole prerogative. God, however, is conceived symbolically as a word which best describes man's ability to create and, because this was traditionally ascribed to God, it can be argued that creativity is a divine feature of humanity. With Schelling in mind, Žižek is able to argue in the end that the logos defines not only man's divine capacity to create material or non-material things, but also the entire human being. Schelling's later thought, which insists on God's prehistory and pre-existence, is not an indication that God can exist before man's creation; it is rather a confirmation that the non-materiality of the human being, his transcendence, and all the things he cannot fully understand with his reason, precede the actuality of the individual human person. The symbolism of man's spirituality, encapsulated in the idea of God, will always precede as well as follow after certain people's lives and deaths. This is why in Žižek man's existence is fundamentally antagonistic and hence dualistic: the individual human being may be aware of what happens to him as a material organism in the sense that he will be able to use his reason to comprehend his life in the natural world. There are, however, many other things, ideas and concepts which cannot always be explained rationally; the sum of all these things which transcend man's biology and consciousness into the realm of spirituality and unconsciousness - although man is fully aware of their existence - can be attached to the notion of God if man is willing to see himself as divine, as possessing as well as being the logos, a concept which in Žižek places together divinity and humanity, spirituality and materiality, unconsciousness and consciousness in the material existence of the individual human person.

\section{Acknowledgements Competing interests}

The author declares that he has no financial or personal relationship(s) that may have inappropriately influenced him in writing this article.

\section{References}

Beaumont, D., 2009, 'The "Lone-Nut" theory. Paranoia and recognition in contemporary American fiction', in P.E. Kennedy \& M. Lawrence (eds.), Recognition: The poetics of narrative. Interdisciplinary Studies on Anagnorisis, pp. 193-212, Peter Lang, New York, NY.

Biddle, I., 2011, Music, masculinity, and the claims of history. The Austro-German tradition from Hegel to Freud, Ashgate, Farnham.

Böhm, S. \& Batta, A., 2010, 'Just doing it: Enjoying commodity fetishism with Lacan', Organization 17(3), 345-361. http://dx.doi.org/10.1177/1350508410363123

Boucher, G., 2005, 'The law as think. Žižek and the graph of desire', in G. Boucher, J. Glynos \& M. Sharpe (eds.), Transversing the phantasy: Critical responses to Slavoj Žižek, pp. 23-46, Ashgate Publishing, Aldershot.

Boucher, G., 2008, The charmed circle of ideology. A critique of Laclau and Mouffe, Butler and Žižek, re.press, Melbourne.

Branch, L., 2006, Rituals of spontaneity: Sentiment and secularism from free prayer to Wordsworth, Baylor University Press, Waco, TX.

Brockelman, T., 2008, Žižek and Heidegger: The question concerning TechnoCapitalism, Continuum, London.

Bronfen, E., 1998, The knotted subject: Hysteria and its discontents, Princeton University Press, Princeton, NJ.

Bucur, I.-M. \& Capota, C., 2007, 'Defining the enemy: The profile of the bourgeoisie in Romanian Communist textbooks', in S.G. Ellis \& L. Klusáková (eds.), Imagining frontiers, contesting identities, pp. 393-412, Pisa University Press, Pisa.

Bulag, U.E., 2010, Collaborative nationalism: The politics of friendship on China's Mongolian Frontier, Rowman \& Littlefield, Lanham, MD

Burke, P., 1999, 'Creativity and the unconscious in Merleau-Ponty and Schelling', in A. Cloots \& S. Sia (eds.) Framing a vision of the world: Essays in philosophy, science, and religion, pp. 183-208, Leuven University Press, Leuven.

Butler, R., 2005, Slavoj Žižek: Live theory, Continuum, London.

Callinicos, A., 2006, The resources of critique, Polity Press, Cambridge.

Chomsky, N., 2013, 'Fantasies', in Znet, viewed 26 August 2013, from http://chomsky. info/articles/20130721.htm

Cooper, S., 2002, Technoculture and critical theory: In the service of the machine?, Routledge, London. http://dx.doi.org/10.4324/9780203167021

Crockett, C., 2007, Interstices of the sublime: Theology and psychoanalytic theory, Fordham University Press, Bronx, NY. http://dx.doi.org/10.5422/ fso/9780823227211.001.0001

De Berg, H., 2003, Freud's theory and its use in literary and cultural studies, Camden House/Boydell \& Brewer, Rochester, NY.

De Cock, C. \& Böhm, S., 2007, 'Liberalist fantasies: Žižek and the impossibility of the open society', Organization 14(6), 815-836. http://dx.doi. org/10.1177/1350508407082264

Dews, P., 1995, The limits of disenchantment: Essays on contemporary European philosophy, Verso, London.

Dicker, G., 2004, Kant's theory of knowledge: An analytical introduction, Oxford University Press, Oxford. http://dx.doi.org/10.1093/0195153065.001.0001

Dodds, J., 2012, 'The ecology of phantasy: Ecopsychoanalysis and the three ecologies', in M.-J. Rust \& N. Totton (eds.), Vital signs: Psychological responses to ecological crisis, pp. 119-133, Karnac Books, London.

Dorrien, G., 2012, Kantian reason and Hegelian spirit: The idealistic logic of modern theology, Wiley-Blackwell, Oxford.

Easthope, A., 1999, The unconscious: The new critical idiom, Routledge, London.

Eyers, T., 2011, 'Lacanian materialism and the question of the real', Cosmos and history: The Journal of Natural and Social Philosophy 7(1), 155-166.

Faflak, J., 2005, 'Afterword: Ross Woodman's romanticism', in R.G. Woodman (ed.), Sanity, madness, transformation: The psyche in Romanticism, pp. 210-235, University of Toronto Press, Toronto.

Fontenelle, I.A., 2010, 'Global responsibility through consumption? Resistance and assimilation in the anti-brand movement', Critical Perspectives on International Business 6(4), 256-272. http://dx.doi.org/10.1108/17422041011086841

Fradenburg, L.O.A., 2002, Sacrifice your love: Psychoanalysis, historicism, Chaucer, University of Minnesota Press, Minneapolis, MN.

Guyer, P., 2006, Kant, Routledge, Abingdon.

Güzeldere, G., 1997, 'Introduction: The many faces of consciousness. A field guide', in N. Block, O. Flanagan \& G. Güzeldere (eds.), The nature of consciousness: Philosophical debates, pp. 1-68, MIT Press, Cambridge, MA.

Hallward, P., 2003, Badiou: A subject to truth, University of Minnesota Press, Minneapolis, MN. 
Hedley, D., 2004, Coleridge, philosophy and religion: Aids to reflection and the mirror of the spirit, Cambridge University Press, Cambridge.

Hendrick, I., 1958, Facts and theories of psychoanalysis, Routledge, London.

Jagodzinzki, J., 1997, Postmodern dilemmas: Outrageous essays in art \& art education, Lawrence Erlbaum, Mahwah, NJ.

Johnston, A., 2008, Žižek's ontology: A transcendental materialist theory of subjectivity, Northwestern University Press, Evanston, IL.

Kapoor, I., 2013, Celebrity humanitarianism: The ideology of global charity, Routledge, New York, NY.

Keenan, D.K., 2005, The question of sacrifice, Indiana University Press, Bloomington, IN.

Keenan, T., 1997, Fables of responsibility: Aberrations and predicaments in ethics and politics, Stanford University Press, Stanford, CA.

King, B., 2010, 'Stardom, celebrity, and the money form', Velvet Light Trap 65(1), 7-19. http://dx.doi.org/10.1353/vlt.0.0084

Kojève, A., 2004, "'The idea of death in the philosophy of Hegel" from Introduction to the Reading of Hegel (1947; lectures delivered: 1933-34)', in D.K. Keenan (ed.) Hegel and continental philosophy, pp. 27-74, State University of New York Press, Albany, NY.

Kotsko, A., 2008, Žižek and theology, T\&T Clark, Edinburgh.

Laughland, J., 2007, Schelling versus Hegel: From German idealism to Christian metaphysics, Ashgate Publishing, Aldershot.

Mancuso, V., 1996, Hegel teologo e l'impardonabile assenza del principe di questo mondo, Piemme, Casale Monferrato.

Mandair, A.-P.S., 2009, Religion and the specter of the West: Sikhism, India, postcoloniality, and the politics of translation, Columbia University Press, New York, NY.

Meylahn, J.-A., 2011, 'Religion and modernity in a secular city: A public Theology of différance', HTS Teologiese Studies/Theological Studies 67(3), 1-8. http://dx.doi. différance', HTS Teologiese
org/10.4102/hts.v67i3.961

Morss, J.R., 1996, Growing critical: Alternatives to developmental psychology, Routledge, London.

Mountford, B., 2011, Christian atheist: Belonging without believing, O-Books, Alresford.

Myers, T., 2003, Slavoj Žižek, Routledge, London.

Newman, S., 2004, 'Interrogating the master: Lacan and radical politics', Psychoanalysis, Culture, and Society 9(3), 298-314. http://dx.doi.org/10.1057/ palgrave.pcs.2100021

Nobus, D., 2000, Jacques Lacan and the Freudian practice of psychoanalysis, Routledge, London.

Norman, J. \& Welchman, A., 2004, 'Introduction: The new Schelling', in J. Norman \& A. Welchman (eds.), The new Schelling, pp. 1-12, Continuum, London.

O'Leary, J.S., 2006, 'Questions to and from a tradition in disarray', in J.P. Manoussakis (ed.), After God: Richard Kearney and the religious turn in continental philosophy pp. 185-208, Fordham University Press, Bronx, NY. http://dx.doi.org/10.5422/ fso/9780823225316.003.0013

Olkowski, D., 1999, Gilles Deleuze and the ruin of representation, University of California Press, Berkeley, CA.

Pang, L., 2012, Creativity and its discontents: China's creative industries and intellectual property rights offenses, Duke University Press, Durham, NC. http:// dx.doi.org/10.1215/9780822394587

Pippin, T., 1999, Apocalyptic bodies. The Biblical end of the world in text and image, Routledge, London.

Pippin, T., 2010, "Behold, I stand at the door and knock": The living dead and apocalyptic dystopia', The Bible and Critical Theory 6(3), 1-15. http://dx.doi. org/10.2104/bc100040

Pound, M., 2008, Žižek: A (very) critical introduction, Eerdmans, Grand Rapids, MI.

Quentin Lauer, S.J., 1982, Hegel's concept of God, State University of New York Press, Albany, NY.

Resch, R.P., 2005, 'What if God was one of us - Žižek's Ontology', in G. Boucher, J. Glynos \& M. Sharpe (eds.), Critical responses to Slavoj Žižek, pp. 89-104, Ashgate Publishing, Aldershot.

Rushdy, A.H., 1992, The empty garden: The subject of late Milton, University of Pittsburg Press, Pittsburg, PA.
Sadoff, D.F., 1998, Sciences of the flesh: Representing body and subject in psychoanalysis, Stanford University Press, Stanford, CA.

Safranski, R., 1989, Schopenhauer and the wild years of philosophy, transl. E. Osers, Harvard University Press, Cambridge, MA.

Schmidt-Biggemann, W., 2004, Philosophia Perennis: Historical outlines of Western spirituality in Ancient, Medieval, and Early Modern thought, Springer, Dordrecht.

Sharpe, M., 2004, Slavoj Žižek: A little piece of the real, Ashgate Publishing, Aldershot.

Sharpe, M. \& Boucher, G., 2010, Žižek and politics: A critical introduction, Edinburgh University Press, Edinburgh.

Shaw, D.Z., 2010, Freedom and nature in Schelling's philosophy of Art, Continuum, London.

Shepherdson, C., 1996, 'The role of gender and the imperative of sex', in J. Copjec (ed.), Supposing the subject, pp. 158-185, Verso, London.

Simuț, C.C., 2013, Secularization in contemporary religious radicalism: An introduction, Deo Publishing, Blandford Forum.

Stan, L., 2011, 'Slavoj Žižek: Mirroring the absent God', in J. Stewart (ed.), Kierkegaard's influence on the social sciences, vol. 13, pp. 297-322, Ashgate Publishing, Farnham.

Swyngedouw, E., 2010, 'Impossible sustainability and the post-political condition' in M. Carreta, G. Concilio \& V. Monno (eds.), Making strategies in spatial planning: Knowledge and values, pp. 185-208, Springer, Dordrecht. http://dx.doi. org/10.1007/978-90-481-3106-8_11

Szkudlarek, T., 2011, 'Semiotics of identity: Politics and education', Studies in the Philosophy of Education 30(2), 113-125. http://dx.doi.org/10.1007/s11217-0119225-z

Thurschwell, P., 2009, Sigmund Freud, 2nd edn., Routledge, New York, NY.

Turnbull, N., 2005, 'Crossing Nietzsche', Theory, Culture, and Society 22(3), 139-149. http://dx.doi.org/10.1177/0263276405053726

Vighi, F., 2010, On Žižek's dialectics: Surplus, subtraction, sublimation, Continuum, London.

Wallen, M., 2005, 'The electromagnetic orgasm and the narrative of primordiality in Schelling's 1815 cosmic history', in J.M. Wirth (ed.) Schelling now: Contemporary readings, pp. 122-135, Indiana University Press, Bloomington, IN.

Wendte, M., 2007, Gottmenschliche Einheit bei Hegel: Eine logische und theologische Untersuchung, Walter de Gruyter, Berlin. http://dx.doi. org/10.1515/9783110921267

Widder, N., 2008, Reflections on time and politics, Pennsylvania State University Press, University Park, PA.

Williams, R.R., 2013, 'The inseparability of love and anguish: Hegel's theological critique of modernity', in A. Nuzzo (ed.), Hegel on religion and politics, pp. 139140 , State University of New York Press, Albany, NY.

Wilson, S., 2013, 'Violence and love (in which Yoko Ono encourages Slavoj Žižek to "give peace a chance",', in G. Matthews \& S. Goodman (eds.), Violence and the limits of representation, pp. 28-48, Palgrave Macmillan, New York, NY.

Wirth, J.M., 2003, The conspiracy of life: Meditations on Schelling and his time, State University of New York Press, Albany, NY.

Wood, K., 2012, Žižek: A reader's guide, Wiley-Blackwell, Oxford.

Žižek, S., 1989, The sublime object of ideology, Verso, London.

Žižek, S., 1994, The metastases of enjoyment: Six essays on woman and causality, Verso, London.

Žižek, S., 1995, 'Hegel, Lacan, Deleuze: Three strange bedfellows', in B.E. Babich (ed.), From Phenomenology to thought, errancy, and desire: Essays in honor of William J. Richardson SJ, pp. 483-499, Kluwer Academic Publishers, Dordrecht. http:// dx.doi.org/10.1007/978-94-017-1624-6_30

Žižek, S., 1997, The abyss of freedom: An essay by Slavoj Žižek and the complete text of Schelling's Die Weltalter (second draft, 1813) transl. J. Norman, University of Michigan Press, Ann Arbor, MI.

Žižek, S., 1998, 'The Cartesian subject versus the Cartesian Theater', in S. Žižek (ed.), Cogito and the unconscious, pp. 247-274, Duke University Press, Durham, NC. Cogito and the unconscious, pp. 247-274, Duke
$\mathrm{http} / / / \mathrm{dx}$.doi.org/10.1215/9780822382126-010

Žižek, S., 2012a, Less than nothing: Hegel and the shadow of dialectical materialism, Verso, London.

Žižek, S., 2012b, Organs without bodies, Routledge, Abingdon.

Žižek, S. \& Gunjević, B., 2012, God in pain: Inversions of apocalypse, Seven Stories Press, New York, NY. 